\title{
Epidemiological Study of Acute Toxicity in Children Admitted to Poison Control Center, Ain Shams University Hospitals during the Year 2012 -A Retrospective Study
}

\author{
Sawsan A. Shalaby, Sonya M. S. Azab, Noha El Rafie ${ }^{1}$ and Hany M. Tawfik ${ }^{2}$ \\ ${ }^{1}$ Forensic Medicine and Clinical Toxicology Department, Faculty of Medicine \\ ${ }^{2}$ Consultant of clinical toxicology and head of the Information System Department, Poison Control Center
}

Ain Shams University, Cairo, Egypt.

\begin{abstract}
Acute poisoning represents a major cause of morbidity and mortality among children. The pattern of incidence and risk factors for acute poisoning in children change with time and differ from country to country. Thus, specific epidemiological studies for each country are necessary for determination of the extent and characteristics of the problem, accordingly appropriate preventive measures can be taken. Aim of the study: This is an epidemiological retrospective study aimed to determine the pattern of acute poisoning in children admitted to PCC, Ain Shams University Hospitals during the year 2012.

Methods: The collected data about the cases included demographic data (age, gender and residence), circumstances of poisoning (substance of exposure; place, time, mode and route of exposure and coingestion of other agents) and cases' outcome (recovery and discharge or death).

Results: This study included 1,521 children; adolescents represented the most frequent age group $(55.6 \%)$, followed by toddlers $(21.9 \%)$. Female gender was more frequent than male $(67.8 \%$ versus $32.2 \%)$. The majority of admitted pediatric cases were resident in Greater Cairo governorates. Drugs were more common cause of poisoning in the included cases than non-medicinal agents $(57.1 \%$ vs $42.9 \%$ ) and theophylline was the most frequent drug. Pesticides were the most frequent non-medicinal agent in all age groups, except for toddlers where chemicals (kerosene and corrosives) were the most frequent agent. Intentional poisoning was more frequent than unintentional poisoning $(55.5 \%$ vs $44.5 \%$ ). While unintentional poisoning occurred in all age groups, intentional poisoning (mainly suicidal) occurred exclusively in older age groups (school age group and adolescents).

The house was the site of exposure to poisons in all cases. The winter was the season of greatest frequency of poisoning by pesticides, gases and drugs while the summer was the season of greatest frequency of animal, food, fish and plant poisoning as well as poisoning by chemicals. Ingestion was the most common route of exposure in all age groups (1484 cases, $97.4 \%)$ and it was the only route of exposure in infants. About $3.5 \%$ of the included cases $(59$ cases) were presented with co-ingestion of other substances; most of them were in the adolescent group. The percentage of mortality of the admitted cases was $2.2 \%$ (33 cases). Iatrogenic/ therapeutic poisoning had the highest mortality ratio $(25 \%)$ followed by accidental poisoning $(2.8 \%)$ and suicidal poisoning (1.4\%).

Conclusion: The greatest frequency of poisoning in children was in adolescents, followed by toddlers. Oral route was the most common route of exposure. Poisoning in children may occur unintentional (in all age group) or intentional (only in older age groups). Suicidal poisoning was the main manner of exposure in adolescents. The percentage of mortality was $2.2 \%$.

Recommendations: Appropriate injury prevention strategies, such as safe storage of medicines and cleaning supplies should be implemented. Also, more restrictive measures on the use and storage of pesticides should be taken.

Further studies on the risk factors of deliberate self-poisoning in adolescents are recommended as it was found as a major manner of exposure to poisoning in this stage.
\end{abstract}




\section{Introduction}

$\mathrm{P}$ oisoning refers to an injury that results from being exposed to an exogenous substance that causes cellular injury or death (Asghar et al., 2010). Acute toxicity refers to those adverse effects occurring following oral or dermal administration of a single dose of a substance, or multiple doses given within 24 hours, or an inhalation exposure of 4 hours (United Nations, 2009).

The hazard of poisoning have been increased in the recent decades due to rapid industrialization and exposure to hazardous chemical products, introduction of newer range of drugs for treatment, massive use of pesticides in agriculture and unhealthy dietary habits. All these factors had widened the spectrum of toxic products to which people with different ages are exposed (Kiran et al., 2008).

The prevalence and types of poisoning vary considerably across the world and depend on socioeconomic status and cultural practices, as well as on local industrial and agricultural activities. The incidence and risk factors for acute poisoning in children change with time and differ from country to other, and even between geographical areas within the same country (Goto et al., 2011).

This study aims to determine the pattern of acute poisoning in children admitted to Poison Control Center (PCC), Ain Shams University Hospitals during a one year period starting from 1/1/2012 to 31/12/2012. Such epidemiological study is necessary to determine the extent and characteristics of pediatric poisoning, accordingly related appropriate measures for both prevention and treatment can be taken.

\section{Subjects and Methods}

This retrospective study was carried out on all acutely poisoned children of both sexes, aged $\leq 18$ years old who were admitted to PCC, Ain Shams University Hospitals, during one year period starting from $1 / 1 / 2012$ to 31/12/2012. The study included all admitted cases to inpatient and intensive care unit (ICU).

An official permission was taken from the director of the PCC. The approval of The Local Research Ethics Committee was obtained. All personal data were kept anonymous to ensure confidentiality of records.

The medical records for the included pediatric patients were revised and the following data were obtained:

-Patients' sociodemographic characteristics: age, gender and residence.

-Circumstances of poisoning: agents responsible for poisoning, manner of exposure (intentional or unintentional), place and time of poisoning, route of exposure, presence of co- ingestion of other drugs or agents.
-Outcome of the case: either recovery and discharge or death.

For comparison of poisoning between age groups; the included cases were subdivided into: infants (less than one year old), toddlers (1: $<3$ years old), preschool age group $(3:<6$ years old), school age group (6: <12 years old) and adolescents (12: 18 years old) (Kail, 2004).

\section{Statistical Analysis}

The obtained data was analyzed using Statistical package for Social Science (SPSS) version 19 software. Chi-square test was used for comparison of frequencies of qualitative variables between groups. All measured $(\mathrm{P})$ values were two-sided. $\mathrm{P}<0.05$ was considered significant.

\section{Results}

During the study period, a total of 16,003 cases of poisoning were received at the PCC; pediatric cases represented $43.2 \%$ (6,908 cases). This study included 1,521 children who were admitted to the center and represented about $22 \%$ of the total pediatric cases.

Table (1) shows demographic analysis (age, gender and residence) of the studied cases. Adolescents represented the most frequent age group among the admitted pediatric cases $(55.6 \%)$, followed by toddlers $(21.9 \%)$. Female gender was more frequent than male $(67.8 \%$ versus $32.2 \%)$. The majority of admitted pediatric cases were residents in Greater Cairo governorates (Cairo $(58.4 \%)$, Kaliobeya (20.4\%) and Giza (15.3\%)).

Table (2) shows the gender distribution in age groups of the included cases. Female gender was predominant in the adolescent and school age groups while male gender was predominant in younger age groups. This difference was statistically significant.

Table (3) shows that, acute poisoning was found to occur due to drugs in $57.1 \%$ (868 cases) and non-medicinal agents in 42.9\% (653 cases). Drugs affecting cardio-pulmonary system (mainly theophylline) had the greatest frequency (383 cases, $44.1 \%$ ) in the included cases, followed by drugs affecting CNS (mainly antiepileptic drugs) (205 cases, $23.6 \%$ ) and substances of abuse (143 cases, $16.5 \%$ ). Tramadol was the most frequent drug of abuse resulting in acute poisoning in the included cases.

Table (4) shows that, the most frequent drug was different between age groups; substances of abuse were the most frequent agent in infants, followed by drugs acting on CNS. Drugs affecting cardiopulmonary system, followed by drugs acting on CNS were the most frequent agent in toddlers, pre-school and adolescent age groups. In school age group, drugs acting on CNS, followed by drugs affecting cardiopulmonary system, were the most frequent.

Table (5) shows the non-medicinal agents that were responsible for acute poisoning in the included cases. Pesticides (mainly organophosphrous insecticides) were the most frequent causative agent 
(477 cases, $73 \%$ ), followed by chemicals (corrosives and kerosene, 119 cases, $18.3 \%$ ).

Table (6) shows that, pesticides were the most frequent agent in all age groups, except for toddler age group where chemicals (corrosive and kerosene) were the most frequent agent, followed by pesticides.

Table (7) shows that, intentional poisoning was more frequent than unintentional poisoning $(55.5 \%$ vs. $45.5 \%$ ). While unintentional poisoning occurred in all age groups, intentional poisoning occurred exclusively in older age groups. Most of cases in young age groups occurred due to accidental exposure to poisons while in the adolescent group, suicidal poisoning was the predominant manner of exposure (95.6\%, 808 cases).

The greatest proportion of poisoning due to illicit drug use was in adolescents $(1.5 \%)$, followed by school age $(1 \%)$. The greatest proportion of iatrogenic poisoning was in infants $(7.1 \%)$, followed by school age group $(5 \%)$.

Regarding place of poisoning, the house was the site of exposure to poisons in all cases.

Regarding seasonal variation, winter was the season of greatest frequency of poisoning by pesticides, gases and drugs. Summer was the season of greatest frequency of animal, food, fish and plant poisoning as well as chemicals (figure (1)).

Table (8) shows that, oral route was the most common route of exposure in all age groups (1484 cases, 97.4\%) and it was the only route of exposure in infants. It was followed by inhalation and animal bite or sting (17 cases, $1.1 \%$ for each). Injection was the least frequent route of exposure to poisoning (one case, $0.1 \%)$.

Figure (2) shows that, there were 59 cases (3.9\% of the included cases) presented with coingestion of other substances. Adolescents represented the greatest proportion of these cases (43 cases, $72.9 \%$ ), followed by the toddlers (10 cases, $16.9 \%$ ). There were no cases with co-ingestion of other substances in infants group.

The outcome of the cases was determined as recovery and discharge from the PCC or death. The percentage of mortality in the admitted cases was $2.2 \%$ (33 cases). Figure (3) shows proportions of mortality according to manner of exposure to poisonous agents in the included cases. Iatrogenic/ therapeutic poisoning had the highest mortality ratio $(25 \%)$ followed by accidental poisoning $(2.8 \%)$ and suicidal poisoning $(1.4 \%)$.

Table (1): Demographic characteristics (age, sex and residence) of poisoned children, admitted to PCC, Ain Shams University Hospitals during the year 2012:

\begin{tabular}{|l|c|c|c|}
\hline \multicolumn{2}{|c|}{ Demographic characteristic } & Number & Percentage (\%) \\
\hline \multirow{4}{*}{ Age } & Infants (<1 Y.) & 28 & 1.8 \\
\cline { 2 - 4 } & Toddlers (1-<3Y.) & 334 & 21.9 \\
\cline { 2 - 4 } & Preschool age (3-<6 Y.) & 214 & 14.1 \\
\cline { 2 - 4 } & School age (6-<12 Y.) & 100 & 6.6 \\
\cline { 2 - 4 } & Adolescents (12-18 Y.) & 845 & 55.6 \\
\hline \multirow{4}{*}{$\begin{array}{l}\text { Gender } \\
\text { governorate }\end{array}$} & Male & 489 & 32.2 \\
\cline { 2 - 4 } & Female & 1032 & 67.8 \\
\cline { 2 - 4 } & Cairo & 889 & 58.4 \\
\cline { 2 - 4 } & Kaliobeya & 310 & 20.4 \\
\cline { 2 - 4 } & Lower Egypt governorates & 60 & 15.3 \\
\cline { 2 - 4 } & Suez canal governorates & 25 & 4 \\
\cline { 2 - 4 } & Upper Egypt governorates & 4 & 1.6 \\
\hline Total & & 1521 & 100 \\
\hline
\end{tabular}

Y.: year $(s)$

Table (2): Chi-square statistical analysis comparing gender distribution in the age groups of acutely poisoned children, admitted to PCC, Ain Shams University Hospitals during the year 2012:

\begin{tabular}{|c|c|c|c|c|c|}
\hline \multirow{2}{*}{ Age group } & \multicolumn{2}{|c|}{ Females } & \multicolumn{2}{|c|}{ Males } & \multirow{2}{*}{ Total } \\
\hline & $\mathbf{N}$ & $(\%)$ & $\mathbf{N}$ & $(\%)$ & \\
\hline Infants (<1 Y.) & 11 & 39.3 & 17 & 60.7 & 28 \\
\hline Toddlers $(1-<3$ Y.) & 160 & 47.9 & 174 & 52.1 & 334 \\
\hline Preschool age $(3-<6$ Y.) & 88 & 41.1 & 126 & 58.9 & 214 \\
\hline School age $(6-<12$ Y.) & 63 & 63 & 37 & 37 & 100 \\
\hline Adolescents (12-18 Y.) & 710 & 84 & 135 & 16 & 845 \\
\hline Total & \multicolumn{2}{|c|}{1032} & \multicolumn{2}{|c|}{845} & 1521 \\
\hline \multirow[t]{2}{*}{ Chi-square } & \multicolumn{5}{|c|}{$X^{2}: 243.9$} \\
\hline & \multicolumn{5}{|c|}{ P-value: $<0.001 *$} \\
\hline
\end{tabular}

N: number, (\%): percentage by age group, Y.: year(s), *: Significant value 
Table (3): Drugs responsible for acute poisoning in children admitted to PCC, Ain Shams University Hospitals during the year 2012:

\begin{tabular}{|c|c|c|c|}
\hline \multicolumn{2}{|c|}{ Causative agent } & \multirow{2}{*}{$\begin{array}{c}\text { Number } \\
258 \\
\end{array}$} & \multirow{2}{*}{$\begin{array}{c}\text { Percentage }(\boldsymbol{\%}) \\
29.7 \\
\end{array}$} \\
\hline Cardio-pulmonary & Theophylline & & \\
\hline & Others $^{\dagger}$ & 125 & 14.4 \\
\hline & Total & 383 & 44.1 \\
\hline \multirow{3}{*}{ CNS drugs } & Antiepileptics & 103 & 11.9 \\
\hline & Others $^{\dagger \dagger}$ & 102 & 11.8 \\
\hline & Total & 205 & 23.6 \\
\hline \multirow[t]{3}{*}{ Drugs of abuse } & Tramadol & 88 & 10.1 \\
\hline & Others ${ }^{\dagger \dagger}$ & 55 & 6.3 \\
\hline & Total & 143 & 16.5 \\
\hline \multicolumn{2}{|l|}{ Anti-diabetic agents } & 79 & 9.1 \\
\hline \multicolumn{2}{|l|}{ Unknown medications } & 31 & 3.6 \\
\hline \multicolumn{2}{|l|}{ Non-opioid analgesics } & 17 & 2 \\
\hline \multicolumn{2}{|l|}{ Miscellaneous $^{\dagger \dagger \dagger \dagger}$} & 10 & 1.2 \\
\hline \multicolumn{2}{|l|}{ Total } & 868 & 100 \\
\hline
\end{tabular}

${ }^{\dagger}$ : Included BBs (62 cases), CCBs (12 cases), digoxin (47cases) and other antihypertensives (4 cases). ${ }^{\dagger}$ : Included anti-depressants (80 cases) and anti-psychotics (22 cases). ${ }^{\dagger t}$ : Included cannabis (23 cases), benzodiazepine (31 cases) and opiates (one case) tht: Included iron supplements (2 cases), primperan (one case), colchicine (5 cases) and anticoagulants (2 cases).

Table (4): Distribution of drugs responsible for acute poisoning in age groups of children admitted to PCC, Ain Shams University Hospitals during the year 2012:

\begin{tabular}{|c|c|c|c|c|c|c|c|c|c|c|c|c|}
\hline \multirow[b]{2}{*}{ Agents } & \multicolumn{2}{|c|}{$\begin{array}{c}\text { Infants } \\
(<1 \text { year })\end{array}$} & \multicolumn{2}{|c|}{$\begin{array}{l}\text { Toddlers } \\
(1-<3 \text { Y. }) \\
\end{array}$} & \multicolumn{2}{|c|}{$\begin{array}{c}\text { Pre-school age } \\
(3-<6 \text { Y. })\end{array}$} & \multicolumn{2}{|c|}{$\begin{array}{c}\text { School age } \\
(6-12 \text { Y.) }\end{array}$} & \multicolumn{2}{|c|}{$\begin{array}{c}\text { Adolescents } \\
\text { (12-18 Y.) }\end{array}$} & \multicolumn{2}{|c|}{ Total } \\
\hline & $\mathbf{N}$ & $\%$ & $\mathbf{N}$ & $\%$ & $\mathbf{N}$ & $\%$ & $\mathbf{N}$ & $\%$ & $\mathbf{N}$ & $\%$ & $\mathbf{N}$ & $\%$ \\
\hline Cardio-Pulmonary drugs & 1 & 5 & 50 & 29.8 & 42 & 35.9 & 17 & 31.5 & 273 & 53.6 & 383 & 44.1 \\
\hline CNS Drugs & 6 & 30 & 49 & 29.2 & 37 & 31.6 & 18 & 33.3 & 95 & 18.7 & 205 & 23.6 \\
\hline $\begin{array}{l}\text { Substances } \\
\text { Of Abuse }\end{array}$ & 12 & 60 & 44 & 26.2 & 30 & 25.6 & 8 & 14.8 & 49 & 9.6 & 143 & 16.5 \\
\hline Non-opioid analgesics & 0 & 0 & 3 & 1.8 & 3 & 2.6 & 0 & 0.0 & 11 & 2.2 & 17 & 2.0 \\
\hline Unknown & 0 & 0 & 7 & 4.2 & 5 & 4.3 & 8 & 14.8 & 11 & 2.2 & 31 & 3.6 \\
\hline Anti-Diabetic agents & 0 & 0 & 14 & 8.3 & 0 & 0 & 2 & 3.7 & 63 & 12.4 & 79 & 9.1 \\
\hline Miscellaneous $^{\dagger}$ & 1 & 5 & 1 & 0.6 & 0 & 0 & 1 & 1.9 & 7 & 1.4 & 10 & 1.2 \\
\hline Total & 20 & 100 & 168 & 100 & 117 & 100 & 54 & 100 & 509 & 100 & 868 & 100 \\
\hline
\end{tabular}

Y.: year(s), N: number, \%: percentage ${ }^{\dagger}$ : included iron supplements (2 cases), primperan (one case), colchicine(5cases) and anticoagulants (2 cases). 
Table (5): The non-medicinal agents resulting in acute poisoning in children admitted to PCC, Ain Shams University Hospitals during the year 2012:

\begin{tabular}{|c|c|c|c|c|}
\hline \multicolumn{2}{|c|}{ Causative agent } & \multirow{2}{*}{$\begin{array}{c}\text { Number } \\
220\end{array}$} & \multirow{2}{*}{$\begin{array}{c}\begin{array}{c}\text { Percentage } \\
(\%)\end{array} \\
33.7\end{array}$} & \multirow{3}{*}{$\begin{array}{c}\text { Total } \\
477(73 \%)\end{array}$} \\
\hline \multirow[t]{3}{*}{ Pesticides } & $\begin{array}{l}\text { Organophosphrous } \\
\text { compounds }\end{array}$ & & & \\
\hline & Zinc phosphide & 134 & 20.5 & \\
\hline & Carbamates & 123 & 18.8 & \\
\hline \multirow[t]{2}{*}{ Chemical substances } & Corrosives & 86 & 13.2 & \multirow{2}{*}{$\begin{array}{c}119 \\
(18.3 \%)\end{array}$} \\
\hline & Kerosene & 33 & 5.1 & \\
\hline \multirow{2}{*}{$\begin{array}{l}\text { Fish, food and plant } \\
\text { poisoning }\end{array}$} & Ciguatera & 9 & 1.4 & \multirow{2}{*}{$\begin{array}{c}18 \\
(2.8 \%)\end{array}$} \\
\hline & Others $^{\dagger}$ & 9 & 1.4 & \\
\hline \multirow[t]{2}{*}{ Animal poisoning } & Scorpion sting & 10 & 1.5 & \multirow{2}{*}{$\begin{array}{c}17 \\
(2.6 \%)\end{array}$} \\
\hline & Snake bite & 7 & 1.1 & \\
\hline \multirow[t]{2}{*}{ Gases } & $\mathrm{CO}$ & 14 & 2.1 & \multirow{2}{*}{$\begin{array}{c}16 \\
(2.4 \%)\end{array}$} \\
\hline & $\mathrm{H}_{2} \mathrm{~S}$ & 2 & 0.3 & \\
\hline \multicolumn{2}{|l|}{ Miscellaneous $^{\dagger \dagger}$} & 6 & 0.9 & $\begin{array}{c}6 \\
(0.9 \%) \\
\end{array}$ \\
\hline \multicolumn{2}{|l|}{ Total } & 653 & 100 & 100 \\
\hline
\end{tabular}

$\mathrm{H}_{2} \mathrm{~S}$ : hydrogen sulphide gas ${ }^{\dagger}$ : included: food poisoning (3 cases) and castor oil seeds (6 cases) ${ }^{\dagger}$ : included: hypernatremia (2 cases), paraphenylene Diamine (one case), silver nitrate (one case), dormex (one case) and cyanide (one case).

Table (6): Classification of non-medicinal agents responsible for acute poisoning in relation to age groups of children admitted to PCC, Ain Shams University Hospitals during the year 2012:

\begin{tabular}{|c|c|c|c|c|c|c|c|c|c|c|c|c|}
\hline \multirow{2}{*}{ Agents } & \multicolumn{2}{|c|}{$\begin{array}{l}\text { Infants } \\
(<1 \mathrm{Y} .)\end{array}$} & \multicolumn{2}{|c|}{$\begin{array}{l}\text { Toddlers } \\
(1-<3 \text { Y.) }\end{array}$} & \multicolumn{2}{|c|}{$\begin{array}{c}\text { Preschool } \\
\text { age } \\
(3-<6 \text { Y.) }\end{array}$} & \multicolumn{2}{|c|}{$\begin{array}{c}\text { School age } \\
(6-<12 \mathrm{Y} .)\end{array}$} & \multicolumn{2}{|c|}{$\begin{array}{c}\text { Adolescents } \\
(12-18 \text { Y.) }\end{array}$} & \multicolumn{2}{|c|}{ Total } \\
\hline & $\mathrm{N}$ & $\%$ & $\mathrm{~N}$ & $\%$ & $\mathrm{~N}$ & $\%$ & $\mathrm{~N}$ & $\%$ & $\mathrm{~N}$ & $\%$ & $\mathrm{~N}$ & $\%$ \\
\hline Pesticides & 5 & 63 & 78 & 47.0 & 56 & 57.7 & 24 & 52.2 & 314 & 94 & 477 & 73 \\
\hline Chemicals & 2 & 25 & 80 & 48.2 & 31 & 32 & 5 & 10.9 & 1 & 0 & 119 & 18.3 \\
\hline $\begin{array}{l}\text { Fish, Food } \\
\& \text { plant poisoning }\end{array}$ & 0 & 0 & 2 & 1.2 & 7 & 7.3 & 2 & 4.3 & 7 & 2 & 18 & 2.8 \\
\hline Animal poisoning & 0 & 0 & 4 & 2.4 & 1 & 1 & 7 & 15.2 & 5 & 1 & 17 & 2.6 \\
\hline Gases & 0 & 0 & 2 & 1.2 & 1 & 1 & 7 & 15.2 & 6 & 2 & 16 & 2.4 \\
\hline Miscellaneous $^{\dagger}$ & 1 & 13 & 0 & 0 & 1 & 1 & 1 & 2.2 & 3 & 1 & 6 & 0.9 \\
\hline Total & 8 & 100 & 166 & 100 & 97 & 100 & 46 & 100 & 336 & 100 & 653 & 100 \\
\hline
\end{tabular}

Y.: year(s), N: number, \%: percentage, ${ }^{\dagger}$ : included: Hypernatremia (2 cases), PPD (one case), silver nitrate (one case), dormex (one case) and cyanide (one case). 
Table (7): Distribution of manner of exposure to poisons in age groups of the pediatric poisoned patients admitted to PCC, Ain Shams University Hospitals during the year 2012:

\begin{tabular}{|c|c|c|c|c|c|c|c|c|}
\hline \multicolumn{3}{|c|}{$\begin{array}{l}\text { Manner } \\
\text { Of exposure }\end{array}$} & $\begin{array}{l}\text { Infants } \\
(<1 \mathrm{Y} .)\end{array}$ & $\begin{array}{l}\text { Toddlers } \\
(1-<3 \text { Y.) }\end{array}$ & $\begin{array}{c}\text { Preschool } \\
\text { age } \\
(3-<6 \text { Y. })\end{array}$ & $\begin{array}{l}\text { School } \\
\text { age }(6- \\
<12 \mathrm{Y} .)\end{array}$ & $\begin{array}{c}\text { Adolescents } \\
\text { (12-18 Y.) }\end{array}$ & Total \\
\hline \multirow{3}{*}{ : } & Suicidal & $\begin{array}{c}\mathrm{N} \\
(\%)\end{array}$ & $\begin{array}{c}0 \\
(0)\end{array}$ & $\begin{array}{c}0 \\
(0)\end{array}$ & $\begin{array}{c}0 \\
(0)\end{array}$ & $\begin{array}{c}21 \\
(21)\end{array}$ & $\begin{array}{c}808 \\
(95.6)\end{array}$ & $\begin{array}{c}829 \\
(54.5)\end{array}$ \\
\hline & $\begin{array}{l}\text { Substance of } \\
\text { abuse } \\
\text { overdose }\end{array}$ & $\begin{array}{l}\mathrm{N} \\
(\%)\end{array}$ & $\begin{array}{c}0 \\
(0)\end{array}$ & $\begin{array}{c}0 \\
(0)\end{array}$ & $\begin{array}{c}0 \\
(0)\end{array}$ & $\begin{array}{c}1 \\
(1)\end{array}$ & $\begin{array}{c}13 \\
(1.5)\end{array}$ & $\begin{array}{c}14 \\
(0.9)\end{array}$ \\
\hline & Criminal & $\begin{array}{c}\mathrm{N} \\
(\%)\end{array}$ & $\begin{array}{c}0 \\
(0)\end{array}$ & $\begin{array}{c}0 \\
(0)\end{array}$ & $\begin{array}{c}0 \\
(0)\end{array}$ & $\begin{array}{c}0 \\
(0)\end{array}$ & $\begin{array}{c}1 \\
(0.1)\end{array}$ & $\begin{array}{c}1 \\
(0.1)\end{array}$ \\
\hline \multirow{2}{*}{\multicolumn{2}{|c|}{ 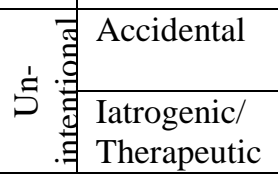 }} & $\begin{array}{c}\mathrm{N} \\
(\%)\end{array}$ & $\begin{array}{c}26 \\
(92.9) \\
\end{array}$ & $\begin{array}{c}333 \\
(99.7) \\
\end{array}$ & $\begin{array}{c}213 \\
(99.5)\end{array}$ & $\begin{array}{c}76 \\
(76) \\
\end{array}$ & $\begin{array}{c}21 \\
(2.6)\end{array}$ & $\begin{array}{l}669 \\
(44) \\
\end{array}$ \\
\hline & & $\begin{array}{c}\mathrm{N} \\
(\%)\end{array}$ & $\begin{array}{c}2 \\
(7.1)\end{array}$ & $\begin{array}{c}1 \\
(0.3)\end{array}$ & $\begin{array}{c}1 \\
(0.5)\end{array}$ & $\begin{array}{c}2 \\
(2)\end{array}$ & $\begin{array}{c}2 \\
(0.2)\end{array}$ & $\begin{array}{c}8 \\
(0.5) \\
\end{array}$ \\
\hline \multicolumn{2}{|c|}{ Total } & $\begin{array}{c}\mathrm{N} \\
(\%)\end{array}$ & $\begin{array}{c}28 \\
(100)\end{array}$ & $\begin{array}{c}334 \\
(100)\end{array}$ & $\begin{array}{c}214 \\
(100)\end{array}$ & $\begin{array}{c}100 \\
(100)\end{array}$ & $\begin{array}{c}845 \\
(100)\end{array}$ & $\begin{array}{l}1521 \\
(100)\end{array}$ \\
\hline
\end{tabular}

Y.: year(s), $N$ : number, (\%): Percentage by age group

Table (8): Distribution of route of exposure to poisons in age groups of the pediatric poisoned patients admitted to PCC, Ain Shams University Hospitals during the year 2012:

\begin{tabular}{|c|c|c|c|c|c|c|c|}
\hline \multicolumn{2}{|c|}{$\begin{array}{l}\text { Age Groups } \\
\text { Route of } \\
\text { Exposure }\end{array}$} & Infants $(<1 \mathrm{Y})$. & $\begin{array}{l}\text { Toddlers } \\
(1-<3 \text { Y. })\end{array}$ & $\begin{array}{c}\text { Pre-school age } \\
\quad(3-<6 \text { Y.) }\end{array}$ & $\begin{array}{l}\text { School age } \\
(6-<12 \mathrm{Y} .)\end{array}$ & $\begin{array}{c}\text { Adolescents } \\
(12-18 \text { Y.) }\end{array}$ & Total \\
\hline Oral & $\begin{array}{c}\mathrm{N} \\
(\%)\end{array}$ & $\begin{array}{c}28 \\
(100)\end{array}$ & $\begin{array}{c}328 \\
(98.2)\end{array}$ & $\begin{array}{l}212 \\
(99)\end{array}$ & $\begin{array}{c}86 \\
(86)\end{array}$ & $\begin{array}{c}830 \\
(98.3)\end{array}$ & $\begin{array}{c}1484 \\
(97.5)\end{array}$ \\
\hline Inhalation & $\begin{array}{c}\mathrm{N} \\
(\%)\end{array}$ & $\begin{array}{c}0 \\
(0)\end{array}$ & $\begin{array}{c}2 \\
(0.6)\end{array}$ & $\begin{array}{c}1 \\
(0.5)\end{array}$ & $\begin{array}{c}5 \\
(5)\end{array}$ & $\begin{array}{c}9 \\
(0.9)\end{array}$ & $\begin{array}{c}17 \\
(1.1)\end{array}$ \\
\hline Bite/ Sting & $\begin{array}{c}\mathrm{N} \\
(\%)\end{array}$ & $\begin{array}{c}0 \\
(0)\end{array}$ & $\begin{array}{c}4 \\
(1.2)\end{array}$ & $\begin{array}{c}1 \\
(0.5)\end{array}$ & $\begin{array}{c}7 \\
(7)\end{array}$ & $\begin{array}{c}5 \\
(0.7)\end{array}$ & $\begin{array}{c}17 \\
(1.1)\end{array}$ \\
\hline IM-SC & $\begin{array}{c}\mathrm{N} \\
(\%)\end{array}$ & $\begin{array}{c}0 \\
(0) \\
\end{array}$ & $\begin{array}{c}0 \\
(0) \\
\end{array}$ & $\begin{array}{c}0 \\
(0) \\
\end{array}$ & $\begin{array}{c}1 \\
(1)\end{array}$ & $\begin{array}{c}1 \\
(0.1) \\
\end{array}$ & $\begin{array}{c}2 \\
(0.2) \\
\end{array}$ \\
\hline Injection & $\begin{array}{c}\mathrm{N} \\
(\%)\end{array}$ & $\begin{array}{c}0 \\
(0)\end{array}$ & $\begin{array}{c}0 \\
(0)\end{array}$ & $\begin{array}{c}0 \\
(0)\end{array}$ & $\begin{array}{c}1 \\
(1)\end{array}$ & $\begin{array}{c}0 \\
(0)\end{array}$ & $\begin{array}{c}1 \\
(0.1)\end{array}$ \\
\hline Total & $\begin{array}{c}\mathrm{N} \\
(\%)\end{array}$ & $\begin{array}{c}28 \\
(100)\end{array}$ & $\begin{array}{c}334 \\
(100)\end{array}$ & $\begin{array}{c}214 \\
(100)\end{array}$ & $\begin{array}{c}100 \\
(100)\end{array}$ & $\begin{array}{c}845 \\
(100)\end{array}$ & $\begin{array}{l}1521 \\
(100)\end{array}$ \\
\hline
\end{tabular}

Y.: year(s), N: number, (\%): Percentage by age group. IM: intramuscular, SC: subcutaneous.

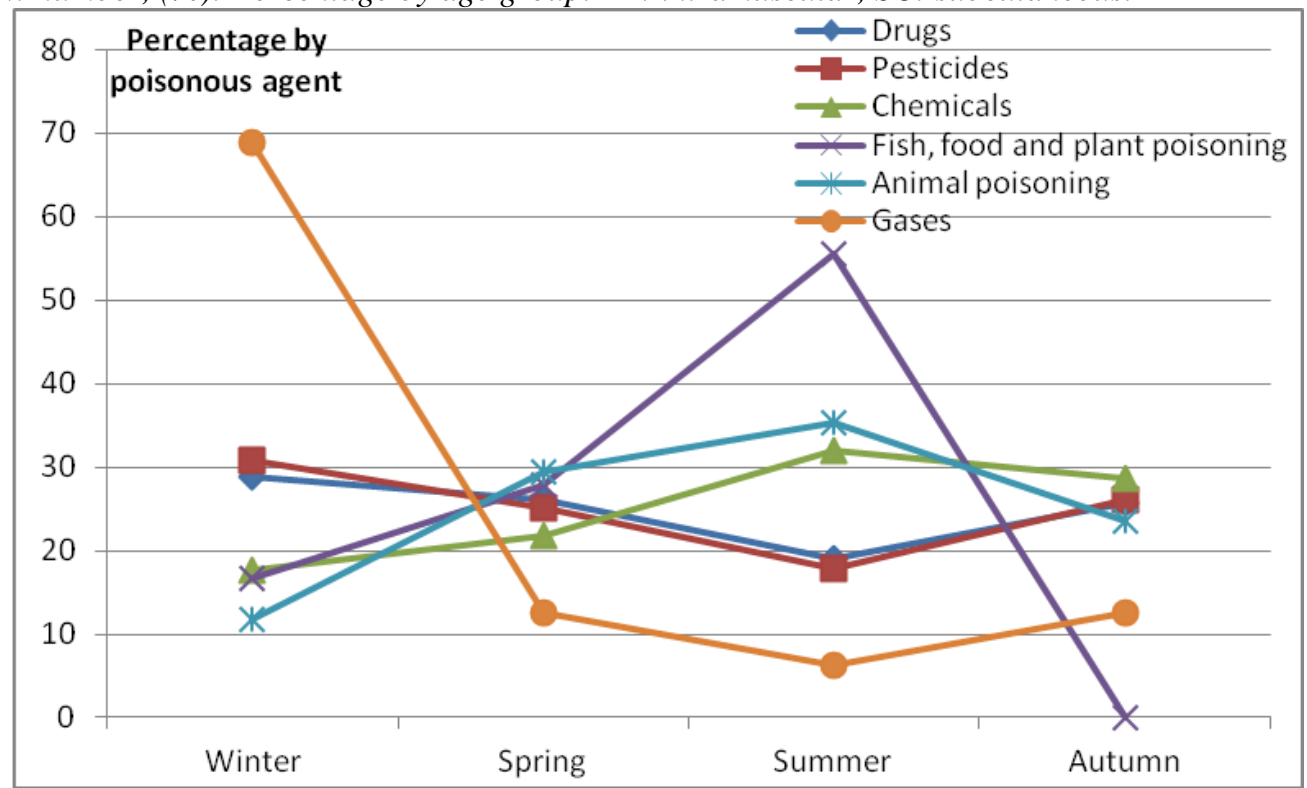

Figure (1): Seasons of exposure to poisonous agents in pediatric poisoned patients admitted to PCC, Ain Shams University Hospitals during the year 2012. 


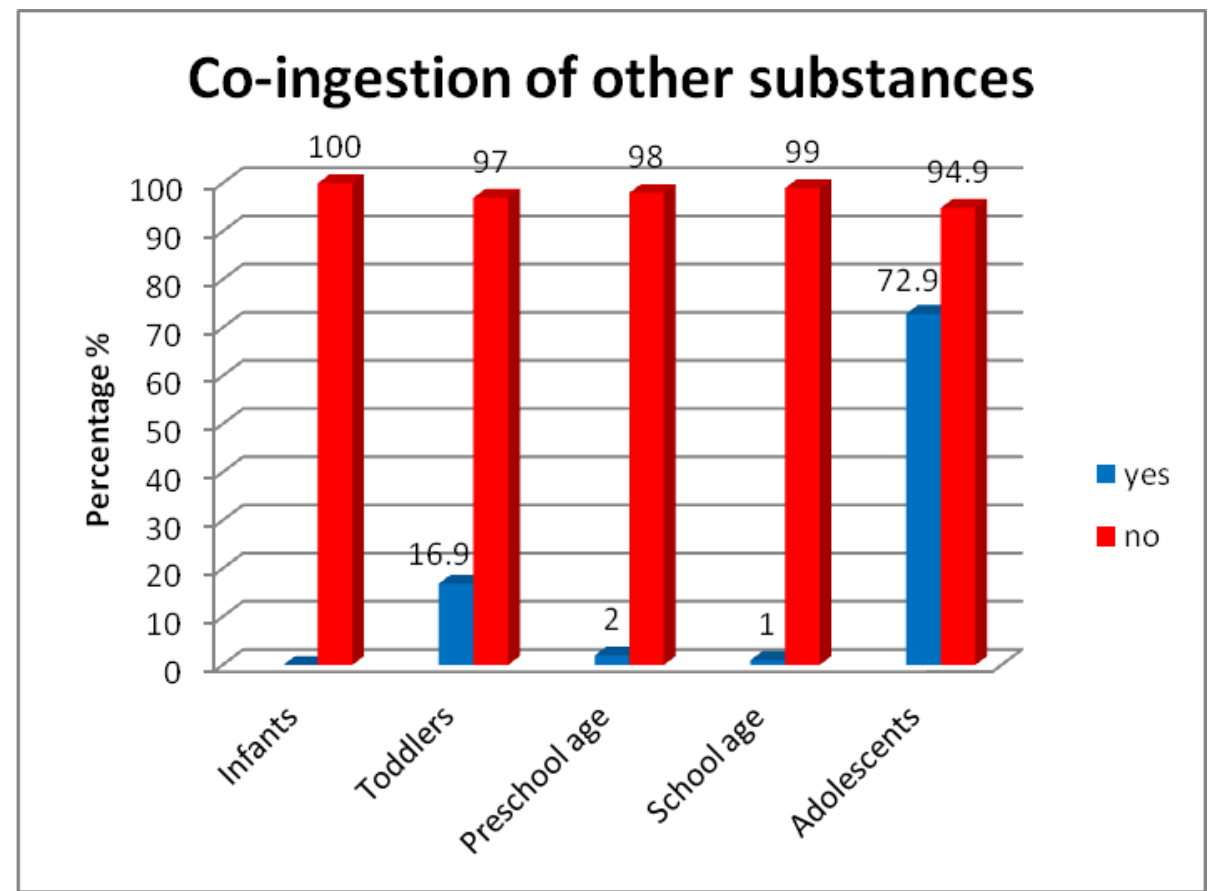

Figure (2): Cases with co-ingestion of other substances in age groups of pediatric poisoned patients admitted to PCC, Ain Shams University Hospitals during the year 2012.

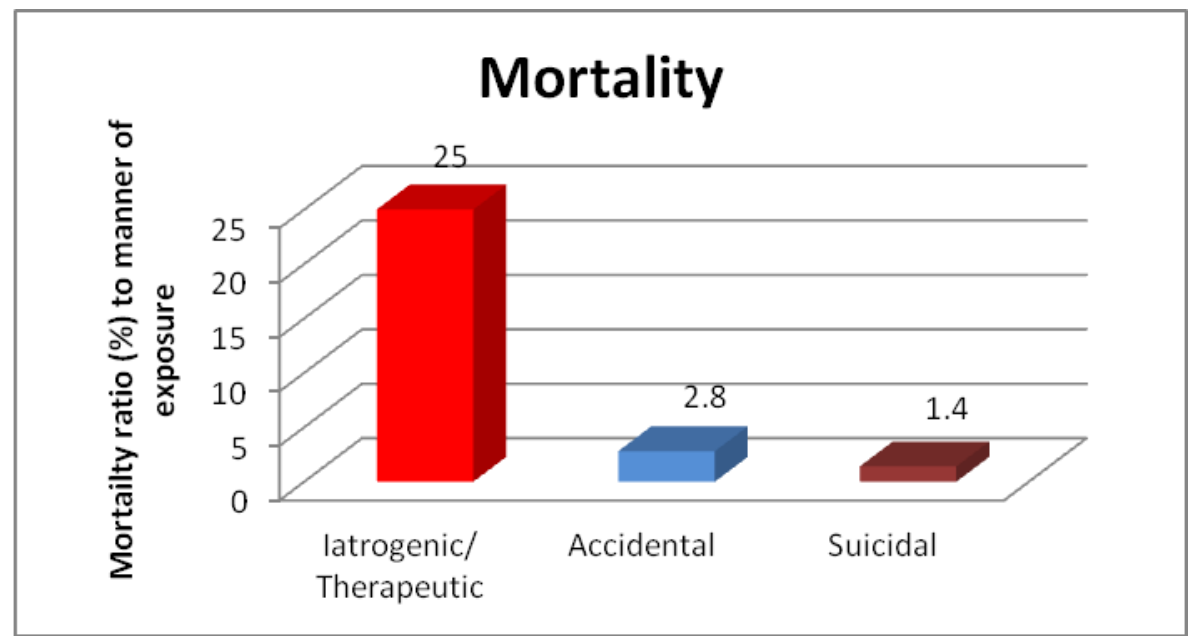

Figure (3): Percentage of mortality according to manner of exposure to poisonous agents in pediatric poisoned patients admitted to PCC, Ain Shams University Hospitals during the year 2012.

\section{Discussion}

Childhood poisoning is a major cause of morbidity and mortality in both the developing and the developed world (Randev et al., 2011). While the developed world has accurate information on incidence and the changing trends of causative agents of pediatric poisoning, this major health problem is still insufficiently studied in the developing countries and incidence of pediatric poisoning is poorly documented (Balme et al., 2012).

The present study found that, admitted children represented only $22 \%$ of the total pediatric cases presented to the PCC during the year 2012. This is in agreement with previous epidemiologic studies that reported that, most of the cases of pediatric poisoning need no medical intervention because the ingested material is either not toxic or the amount swallowed is not clinically significant (Bronstein et al., 2009).

The present study proved that the majority of admitted pediatric population was in the adolescent age group $(55.6 \%)$, followed by the toddler age group (21.9\%).This agreed with Lin et al. (2011) who found adolescents accounted for almost half of the poisoned children presented to the pediatric ED in Taiwan. Haghighat et al., (2013) found that, the most common 
age group was toddlers followed by adolescents the epidemiology of pediatric poisoning in Iran.

This study is in accordance with Hassan and Siam, (2014) who studied acute poisoning in children $\leq 12$ years in Zagazig, Egypt and found that, toddlers constituted $70 \%$ of the cases.

Several epidemiological studies reported two peaks in paediatric poisoning; toddler stage and adolescent stage. This was explained by the stages of development as young children become more mobile and have increased access to toxins. Also, toddlers are curious and explore their world with all their senses, including taste, so, they are putting small foreign objects like drugs into mouth which can cause poisoning. This explains why poisoning rates increase dramatically at around 2 years of age (Eum et al., 2007, Ozdogan et al., 2008, Woo and Ryoo, 2013 and Even et al., 2014).

The increased incidence of poisoning in adolescents was explained by increased self-poisoning in this stage as a results of increased stress on them (from parents, friends, study, jobs, sex and future plans) with which they may fail to cope (Sarjami et al., 2008).

This study revealed that female patients represented the majority of cases $(67.8 \%)$ in comparison to male patients $(32.2 \%)$. Female gender was predominant in the adolescents while male gender was predominant in younger age groups. This is in agreement with Hassan and Siam, (2014) who reported predominance of male gender in poisoned children up to 12 years in Zagazig, Egypt.

Similar findings were reported by Malangu and Ogunbanjo, (2009) who found predominance of male gender in poisoned children younger than 13 years old in South Africa while females were predominant in teenagers and adults. Also, Kivisto et al., (2008) found that, during the first five years of age, boys were more likely to experience multiple incidents of an accidental poisoning than girls. The same

This was explained by the nature of male children as they are more active than females, less obedient to their parents' orders, and is more likely to explore world around them (Kohli et al., 2008, Chowdhury et al., 2009).

Female predominance in adolescents was found to be associated with high rate of suicidal attempts (Hawton et al., 2012 and Haghighat et al., 2013). This was evident in the current study as suicidal poisoning was found to be the most common manner of exposure in adolescents group where the female gender was predominant. This was explained by higher prevalence of psychiatric problems, especially depression, among adolescent young girls (Haghighat et al., 2013). Moreover, studies show that self-harm is more common in female adolescents than that in male adolescents (Tsalkidis et al., 2010).

Regarding the residence of the included cases, most of the cases were resident in Cairo (58.4\%) and nearby governorates (Kaliobeya (20.4\%) and Giza $(15.3 \%)$ ). This could be attributed to the proximity of these governorates to the (PCC), Ain Shams University Hospitals, and not to higher magnitude of poisoning problem (El Masry and Tawfik, 2013).

This study found that, drugs were more frequent cause of pediatric poisoning than nonmedicinal products and cardiopulmonary drugs (mainly theophylline) was the most frequent drug.

The observation of pharmaceutical products as a group being the commonest cause of childhood poisoning is reported by previous studies in Thailand (Chatsantiprapa et al., 2001), Saudi Arabia (Izuora and Adeoye, 2001), Pakistan (Aslam et al., 2002), England (Groom et al., 2006), Turkey (Sahin et al., 2011 and Ozdemir et al., 2012), Greece (Tsalkidis et al., 2010), Kosovo (Azemi et al., 2012) and New Zealand (Fan et al., 2013).

The most likely explanation for these observations was the rise in the number of medications in the environment of children (Bond et al., 2012). In addition, several factors have been found to contribute to increased incidence of pharmaceutical poisoning in children as easy access to pharmaceuticals in many outlets, inadequate knowledge of serious consequences of common drugs, inadequate warning and lack of child- resistant packaging (Woolf and Gardiner, 2010).

Contrary to these results, household products were found to be the most common agent causing pediatric poisoning in New Zealand (Yates, 2003) and USA (Bronstein et al., 2012).

It has been found that, the type of drug causing pediatric poisoning reflects the common drugs used in each community (Woolf and Gardiner, 2010). Theophylline is one of the most common methylxanthines found in pharmaceuticals and was found to be used commonly by adolescents for suicide. It was found to represent an important cause of poisoning with significant morbidity and mortality either due to intentional overdose or iatrogenic due to its narrow therapeutic index. So, adverse effects with acute and chronic overdoses of theophylline are common to occur, even at levels in the therapeutic range (Barnes, 2013).

On the contrary, several epidemiological studies found analgesics as the most commonly encountered drugs in cases with childhood poisoning (Yates, 2003, Rajka et al., 2007, Bronstein et al., 2009, and Koliou et al., 2010). This controversy may be due differences in the study populations as these studies included all cases of pediatric poisoning while the current study included only the admitted cases while analgesics result in none or minor manifestations which rarely require admission.

Pesticides (mainly organophosphorous compounds (OPC)) were the most frequent nonmedicinal agent causing pediatric poisoning in all age groups, except for toddler age group where chemicals (kerosene and corrosives) were the most frequent agent

Previous studies in Egypt revealed variable results; pesticides, followed by drugs and cleaning and disinfectant agents, were the most frequent causative agents in poisoned children $(\leq 12$ years $)$ in Zagazig 
(Hassan and Siam, 2014) while food poisoning, followed by drugs and household agents, was the most common cause of poisoning in Tanta (Maklad and ElSaleet, 1999). Household agents, followed by food poisoning and drugs, were the leading cause of acute poisoning among children in Alexandria (Abd ElMegid and Salem, 1995). This variation may be due to differences in the studied cases either in age groups or severity of poisoning.

The findings of the current study are in accordance with Memon et al., (2010), Randev et al., (2011) and Bhat et al., (2012) who found (OPC) as the most common causative agent of pediatric poisoning in India.

Acute poisoning with pesticides is a public health problem specially in developing countries. Among pesticide poisoning, organophosphates represent a major global problem with thousands of deaths occurring every year particularly in rural areas. This is due their wide use in agriculture and at home without sufficient awareness about their safe handling and storage from children (Asghar et al., 2010). Unfortunately, they are still used for antiscabies treatment and cleansing of the hair from pediculosis due to low health education. Moreover, they are common to be used in suicide attempts due to easy accessibility (Azemi et al., 2012 and Chitra et al., 2013).

The incidence of pesticide poisoning tends to be higher among children from lower socioeconomic class of society due to poor storage facility and parental negligence. Also, inexperience, lack of maturity, illiteracy and inability to assess the risk make them prone for accidental ingestion (Rajendiran et al., 2009).

This study is in agreement with other epidemiological studies in developing countries as Nigeria (Adejuyigbe et al., 2002) and South Africa (Balme et al., 2012), which found kerosene as the most common cause of poisoning in very young children. This was explained by wide use of kerosene as a fuel for cooking and other purposes in most of the developing countries. Also, it is sold openly and families buy and store it in their own containers. Soft drink bottles are often used for its storage and these are kept in the kitchen. Children often mistake it for soft drinks (Tshiamo, 2009).

This study found that, pediatric poisoning occurred either unintentional (in all age groups) or intentional poisoning (exclusively in older age groups; school age group and adolescents). Intentional poisoning (mainly suicidal) was more frequent than unintentional poisoning.

This is in agreement with Bhat et al. (2012) who studied profile of poisoning in children and adolescents in North India and found $97.2 \%$ of children aged $\leq 6$ years had accidental poisoning, compared to homicidal $(2.8 \%)$, and none with suicidal poisoning while $80.9 \%$ of children aged $12-18$ years had intentionally ingested the poison.
It also agreed with Even et al., (2014) who studied poisoned children admitted to pediatric ICU in New England and found that unintentional poisoning was present in all age groups while there were no intentional poisonings in children below 10 years.

Accidental poisonings usually involve toddlers and young children who ingest a small amount of a toxic substance usually result from oral exploration; typically they are taken by a family member for medical care soon after ingestion (Maureen, 2008). In school-age children, child abuse or neglect is highly suspected as a reason for the ingestion. In adolescents and young adults, overdoses are usually suicidal but may also result from drug abuse or experimentation (Dempsey, 2012).

Randev et al. (2011) reported several reasons for higher prevalence of accidental poisoning in children as medication errors, improper storage of poisonous products and look-alike packings.

Intentional administration may occur in older ages; in school-age children where child abuse or negligence may be a reason for the ingestion. On other hand, several developmental factors in adolescents predispose to intentional poisoning as increased risktaking behaviors, low levels of harm avoidance, anxiety, tendency to act impulsively and ignoring the negative consequences of their behavior. All these factors may lead the adolescents to initiate alcohol and illicit drug use which often progressing to substance dependence and substance-related problems (Dawes et al., 2008 , Ringenberg et al., 2013).

This study showed that, the house was the site of exposure to poisons in all included cases. This agreed with several studies that found most of exposure to poisons in pediatric cases occurred at home as it represent the surrounding environment of the children in most times, especially the young children (Bentur et al., 2010, Alazab, 2012, Ugwu et al., 2012).

The current study revealed seasonal variation in the incidence of poisoning since the summer was the season of greatest incidence of animal, food, fish and plant poisoning; as well as chemicals poisoning while the winter was the season of greatest incidence of poisoning by pesticides, gases and drugs.

Shotar, (2005) found that, summer was the time of greatest risk for the ingestion of chemicals due to intense heat causing extreme thirst and sometimes dehydration. The children will drink eagerly when they have access to the fluids so the amount of ingested poison is proportionate to the degree of thirst.

Incidence of food poisoning was found to increase in the summer months due to high temperatures which enhance multiplication of pathogenic micro-organisms in food (Miragliaa et al., 2009). Also, animal poisoning was found to increase during the summer months as animals are more active during the hot season and less active during the colder seasons (Sawalha et al., 2010).

On the other hand, the winter was found to be the time of greatest incidence of poisoning by certain drugs as cough or cold medicines, (as these are often 
considered harmless and left unattended) and carbon monoxide poisoning from heating appliances (Yee et al., 2010).

Ingestion was the most common route of exposure to poisons in all age groups in the current study, followed by inhalation and animal bite/sting via skin. Similar findings were reported by several studies on pediatric poisoning as they found ingestion was the main route of exposure in all age groups (Cengiz et al., 2006, Cheng et al., 2006, Sarjami et al., 2008, Manzar et al., 2010 and Sahin et al., 2011). This was attributed to its convenience and easy availability of orally consumable poisons, in addition to children's propensity to eat everything (Tarvadi et al., 2013).

Most of pediatric poisoning in this study caused by a single agent except for cases presented with co-ingestion. Adolescents showed the greatest proportion of these cases. This is in accordance with Bronstein et al. (2009), Balme et al. (2012), Ozdemir et al. (2012) and Even et al. (2014) who found that, most cases of pediatric poisoning caused by a single toxin.

Ingestion of several substances by adolescents was reported by previous studies and this was related to the manner of exposure. Intentional toxin ingestions for suicide or substance abuse are more common in adolescents and adults. These ingestions usually involve more than one substance and are more often fatal than unintentional ingestion (Bronstein et al., 2011).

Regarding cases' outcome, this study found percentage of mortality in the included cases $2.2 \%$. The mortality rate due to acute poisoning ranges from $0.4 \%$ to $7.6 \%$ in literature. Previous epidemiological studies found mortality of pediatric poisoned patients ranged from 3-5\% (Momen et al., 2010, Mutlu et al., 2010 and Sahin et al., 2011). Deaths from poisoning are far more common in adults than in children (Eldridge et al., 2007).

The morbidity and mortality in any case of acute poisoning depends upon number of factors such as nature of poison, dose consumed, level of availability of medical facilities and delay time between intake of poison and provision of medical help (Kiran et al., 2008). It has been found that childresistant packing, early recognition of exposure and improved medical managements have led to decreased mortality arising from acute pediatrics poisonings (Winchester et al., 2010).

This study found that, iatrogenic/therapeutic poisonings had the greatest proportion of mortalities, followed by accidental and suicidal poisoning. This agreed with Ozdemir et al. (2012) where the highest mortality ratios in poisoned children in Turkey were in the therapeutic, accidental and suicidal poisonings respectively. Lower mortality rate in suicidal poisoning was explained by the intent behind the suicide attempts since most cases aimed to draw attention and/or scare one's parents, rather than to inflict real harm or cause death. This is of course achieved by taking less toxic drugs in smaller amounts.
In contrast, other studies on childhood poisoning reported higher mortality rates in suicidal poisoning when compared to that in accidental poisoning (Bronstein et al., 2007, Powers et al., 2007).

\section{Conclusion}

The greatest frequency of poisoning in children was in adolescents, followed by toddlers. Oral route was the most common route of exposure. Poisoning in children may occur unintentional (in all age group) or intentional (only in older age groups). Suicidal poisoning was the main manner of exposure in adolescents. The percentage of mortality was $2.2 \%$.

\section{Recommendations}

Appropriate injury prevention strategies, such as safe storage of drugs and cleaning supplies should be implemented. Also, more restrictive measures on the use and storage of pesticides should be taken.

Further studies on the risk factors of deliberate self-poisoning in adolescents are recommended as it was found as a major manner of exposure to poisoning in this stage.

Further similar multicenter studies in different governorates are recommended to study the epidemiological pattern of the whole country.

\section{References}

Abd El-Megid LAN and Salem EM, (1995): Children poisoning, prevention

strategies. Mansoura Journal of Forensic Medicine and Toxicology; 3(2): 71-85. In: Maklad AI, Emara AM and El-Maddah EI et al., (2012): Pediatric poisoning in Egypt. Journal of Applied Pharmaceutical Science; 2 (2): 1-6

Adejuyigbe EA, Onayade AA, Senbanjo IO et al., (2002): Childhood poisoning at the Obafemi Awolowo University Teaching Hospital, IleIfe, Nigeria. Niger J Med; 11(4): 183-6.

Alazab RM (2012): Determinants of Acute Poisoning among Children (1-60) months Old at a Poisoning Unit of a University Hospital, Egypt, are employed mothers a risk factor?, retrospective cohort study. Journal of American Science; 8(9): 1107-17.

Asghar A, Anees M and Mahmood KT, (2010): Accidental Poisoning In Children. J Biomed Sci Res; 2: 284-9.

Aslam M, Boluch, GR, Hussain et al., (2002): Accidental poisoning in children. Pak Paed J; 26: 67-70.

Azemi M, Berisha M, Kolgeci S et al., (2012): Frequency, etiology and several sociodemographic characteristics of acute poisoning in children treated in the intensive care unit. Materia socio-medica; 24(2): 76-80.

Balme K, Roberts JC, Glasstone M et al., (2012): The changing trends of childhood poisoning at a tertiary children's hospital in South Africa. SAMJ; 102(3): 142-146. 
Barnes PJ, (2013): Theophylline. Am J Respir Crit Care Med.; 188(8): 901-6.

Bentur Y, Obchinikov ND, Cahana A et al., (2010): Pediatric poisonings in Israel: National Poison Center data. IMAJ; 12(9): 554-9.

Bhat NK, Dhar M, Ahmad S et al., (2012): Profile of poisoning in children and adolescents at a North Indian tertiary care centre. JIACM; 13(1): 37-42.

Bond GR, Woodward RW and Ho M, (2012): The growing impact of pediatric pharmaceutical poisoning. The Journal of pediatrics; 160(2): 265-70.

Bronstein AC, Spyker DA, Louis R et al., (2007): 2006 Annual report of the American Association of Poison Control Centers, National Poison Data System (NPDA). Clinical Toxicology; 45(8): 815 - 917.

Bronstein AC, Spyker DA, Cantilena LR et al., (2009): 2008 Annual report of the American Association of Poison Control Centers' National Poison Data System (NPDS): 26th Annual Report. Clinical Toxicology; 47(10): 911-1084.

Bronstein AC, Spyker DA, Cantilena LR et al., (2011): 2010 Annual report of The American Association Of Poison Control Centers' National Poison Data System (NPDS): 28th annual report. Clinical Toxicology; 49(10): 910-41.

Bronstein AC, Spyker DA, Cantilena LR et al., (2012): 2011 Annual report of The American Association Of Poison Control Centers' National Poison Data System (NPDS): 29th annual report. Clinical Toxicology, 50: 9111164.

Cengiz M, Baysal Z, Ganidagli S. et al, (2006): Characteristics of poisoning cases in adult intensive care unit in Sanliurfa, Turkey. Saudi Med J; 2(4):497-502.

Chatsantiprapa K, Chokkanapatik J and Pinpradit N (2001): Host and environmental factors for exposure to poisons: A cross sectional study of preschool children in Thailand. Inj Prev; 7: L 214-17.

Cheng TL, Wright JL, Pearson-Fields AS et al., (2006): The spectrum of intoxication and poisonings among adolescents: surveillance in an urban population. Inj Prev J; 12(2): 129-32.

Chitra GA, Kaur P, Bhatnagar T et al., (2013): High prevalence of household pesticides and their unsafe use in rural South India. International journal of occupational medicine and environmental health; 26(2): 275-82.

Chowdhury SM, Rahman A, Mashreky SR et al., (2009): The horizon of unintentional injuries among children in low-income setting: An Overview from Bangladesh health and injury survey. J Environ Public Health; 35403: 1-6.

Dawes MA, Mathias CW, Richard DM et al., (2008): Adolescent suicidal behavior and substance use: developmental mechanisms. Substance abuse: research and treatment; 2: 13-28.

Dempsey DA, (2012): Comprehensive evaluation and treatment. In: Poisoning \& Drug overdose (6th ed.), Olson KR, Anderson IB, Benowitz NL, Blanc PD, et al. (eds), McGraw-Hill, New York, volume 1: 1-68.

El Masry MK and Tawfik HM, (2013): 2011 Annual Report of the Poison Control Centre of Ain Shams University Hospital, Cairo, Egypt. Ain Shams Journal of Forensic Medicine and Clinical Toxicology; 20: 10-7.

Eldridge DL, Eyk JV and Kornegay C, (2007): Pediatric toxicology. Emerg Med Clin N Am; 15: 283-308.

Eum JP, Suh JS and Kim HM, (2007): Clinical analysis of acute drug intoxication and foreign body ingestion in Wonju: comparison between the 1990s and the 2000s. Korean J Pediatr; 50: $138-42$.

Even KM, Armsby CC and Bateman ST, (2014): Poisonings requiring admission to the pediatric intensive care unit: A 5-year review. Clinical toxicology; 52(5): 519-24.

Fan AY, Che AH, Pan B et al., (2013): Investigating Childhood and Adolescence Poisoning Exposures in New Zealand Reported to the National Poisons Centre during 20002009. Asia Pacific Journal of Medical Toxicology; 2(2): 52-7.

Goto K, Fredrick H, Hamsertksa M et al., (2011): Poisoning in children in Japan. Indian Journal of Pediatrics; (64): 461-8.

Groom L, Kendrick D, Coupland C et al., (2006): Inequalities in hospital admission rates for unintentional poisoning in young children. Injury prevention; 12(3): 166-70.

Haghighat M, Moravej H and Moatamedi M, (2013): Epidemiology of pediatric acute poisoning in Southern Iran: a hospital based study. Bull Emerg Trauma; 1(1): 28-33.

Hassan BA and Siam MG, (2014): Patterns of acute poisoning in childhood in zagazig, egypt: an epidemiological study. International Scholarly Research Notices; 2014: Article ID 245279.

Available at: http://dx.doi.org/10.1155/2014/245279

Hawton K, Saunders KE and O'Connor RC, (2012): Self-harm and suicide in adolescents. The Lancet; 379(9834): 2373-82.

Izuora GI and Adeoye A, (2001): A seven-year review of accidental poisoning in children. Ann Saudi Med 2001; 21:13-5.

Kail RV, (2004): Cognitive development includes global and domain specific processes. MerrillPalmer Quarterly; 50(4): 445-55.

Kiran N, Rani RH and Prakash VJ, (2008): Pattern of poisoning reported at South Indian tertiary care hospital. Indian Journal of Forensic Medicine \&Toxicology; 2(2): 17-9.

Kivisto JE, Mattila VM, Arvola T et al., (2008): Secular trends in poisonings leading to 
hospital admission among Finnish children and adolescents between 1971 and 2005. The Journal of pediatrics; 153(6): 820-24.

Kohli U, Kuttiat VS, Lodha R et al., (2008): Profile of Childhood Poisoning at a Tertiary Care Centre in North India. Indian J Pediatr 2008; 75: 7914.

Koliou M, Ioannou C, Andreou K et al., (2010): The epidemiology of childhood poisonings in Cyprus. European journal of pediatrics; 169(7): 833-38.

Lin Y, Liu TH, Liu TA et al., (2011): Pharmaceutical Poisoning Exposure and Outcome Analysis in Children Admitted to the Pediatric Emergency Department. Ped Neonatol J; 52 (1): 11-7.

Maklad AIA and El-Saleet GMA, (1999): Acute noninsecticidal poisoning in children admitted at Tanta University Hospital and El-Menshawy General Hospital during the year (1998). Proc. 14th Annual Conf. Tanta Faculty Of Medicine On Medicine Into The Next Century, Tanta, April 7-9: 1-7. In: Maklad AI, Emara AM and El-Maddah EI et al., (2012): Pediatric poisoning in Egypt. Journal of Applied Pharmaceutical Science; 2 (2): 1-6

Malangu N and Ogunbanjo GA, (2009): A profile of acute poisoning at selected hospitals in South Africa.South Afr J Epidemiol Infect; 24(2): 14-6.

Manzar N, Saad SMA, Manzar B et al., (2010): The study of etiological and demographic characteristics of acute household accidental poisoning in children - a consecutive case series study from Pakistan. BMC Pediatr; 10(28): 1-6.

Maureen AM, (2008): Responding to pediatric poisoning. Nursing; 38(8): 52-5.

Memon Y, Majeed R, Kolachi H et al., (2010): Clinical spectrum and outcome of accidental poisoning in children. Biomedica; 26: 92-5.

Miragliaa M, Marvinb H, Kleterb GA et al., (2009): Early Awareness of Emerging Risks to Food and Feed Safety; Climate change and food safety: An emerging issue with special focus on Europe. Food Chemical Toxicol; 47(5): 1009-21.

Mutlu M, Cansu A, Karakas T et al., (2010): Pattern of pediatric poisoning in the east Karadeniz region between 2002 and 2006: increased suicide poisoning. Human and Experimental Toxicology; 29(2): 131-136.

Ozdemir R, Bayrakci B, Teksam O et al., (2012): Thirty-three-year experience on childhood poisoning. Turk J Pediatr; 54(3): 251-9.

Ozdogan H, Davutoglu M, Bosnak M et al., (2008): Pediatric poisonings in southeast of Turkey: epidemiological and clinical aspects. Hum Exp Toxicol; 27(1): 45-8.

Powers KS, Cholette JM and Abboud P, (2007): Toxic exposures: diagnosis and management. In: Pediatric Critical Care Medicine Basic
Science and Clinical Evidence, Wheeler DS, Wong HR and Shanley TP (eds), Springer, London: 1621-1641.

Rajendiran C, Ravi G and Subramanian PT, (2009): Organophosphate, carbamate and rodenticide poisoning in children. Indian Journal of Practical Pediatrics; 11(1): 6-14.

Rajka T, Heyerdahl F, Hovda KE et al., (2007): Acute child poisonings in Oslo: a 2 -year prospective study. Acta Paediatr 2007; 96: 1355-59.

Randev S, Grover N, Sharma R et al., (2011): Acute poisoning in children: seven year experience at a tertiary care hospital of north India. Current Pediatric Research; 15(1): 65-8.

Ringenberg T, Kalabalik J and Robinson C, (2013): Binge drinking and alcohol poisoning in the adolescent population.US Pharm; 38(5): 3-6.

Sahin S, Carman KB and Dinleyici EC, (2011): Acute poisoning in children; data of a pediatric emergency unit. Iran J Pediatr; 21 (4): 479-84.

Sarjami S, Hassanian-Moghaddam H, Pajoumand A et al., (2008): Epidemiology of adolescent poisoning in Loghman-Hakim hospital. Pejouhesh; 32(1): 81-5.

Sawalha AF, Sweileh WM, Tufaha MT et al., (2010): Analysis of the pattern of acute poisoning in patients admitted to a governmental hospital in Palestine. Basic \& Clinical Pharmacology \& Toxicology; 107(5): 914-8.

Shotar AM (2005): Kerosene poisoning in childhood: A 6-year prospective study at the Princess Rahmat Teaching hospital. Neuro Endocrinology letters; 26: 835-8.

Su E, Shoykhet M and Bell MJ, (2010): Severe hypernatremia in a hospitalized child: Munchausen by proxy. Pediatric Neurology; 43(4): 270-3.

Tarvadi PV, Bakkannavar SM, Manjunath S et al., (2013): Trends of poisoning among children at kasturba hospital, Manipal. NUJHS; 3(2): 258.

Tsalkidis A, Vaos G, Gardikis S et al., (2010): Acute poisoning among children admitted to a regional university hospital in Northern Greece. Central European Journal of Public Health; 18(4): 219-23.

Tshiamo W, (2009): Paraffin (kerosene)* poisoning in under-five children: A problem of developing countries. International Journal of Nursing Practice; 15(3): 140-4.

Ugwu GI, Okperi BO, Ugwu EN et al., (2012): Childhood poisoning in Warri, Niger Delta, Nigeria: A ten year retrospective study. African Journal of Primary Health Care \& Family Medicine; 4(1): 1-5.

United Nations, (2009): Health hazards. In Globally Harmonized System of Classification and Labelling of Chemicals (GHS) ( $3^{\text {rd }}$ ed.): 109120. United Nations, Geneva. Available online at:http://www.unece.org/trans/danger/publi/gh s/ghs_rev03/English/03e_part3.pdf. 
Winchester JF, Harbord NB and Rosen H, (2010): Management of Poisonings. Core Curriculum 2010. Am J Kidney Dis; 56(4): 788-800.

Woo JH and Ryoo E, (2013): Poisoning in Korean children and adolescents. Pediatric Gastroenterology, Hepatology \& Nutrition; 16(4): 233-9.

Woolf AD and Gardiner P, (2010): Use of complementary and alternative therapies in children. Clinical Pharmacology \& Therapeutics; 87(2): 155-7.
Yates KM, (2003): Accidental poisoning in New Zealand. Emergency Medicine; 15(3): 244249.

Yee BE, Ahmed MI, Brugge D et al., (2010): Second-hand smoking and carboxyhemoglobin levels in children: a prospective observational study. Pediatric Anesthesia; 20(1): 82-89.

\section{دراسة وبائية للتسمم الحاد فى الأطفال الذين أدخلوا مركز علاج التسمم، مستشفيات جامعة عين شمس، خلال عام Y ا • ץ- دراسة استرجاعية}

\section{سوسن ع. شُلبى و سونيا م.س. عزب و نهى أ. مجدى' ه هانى م. توفيق'}

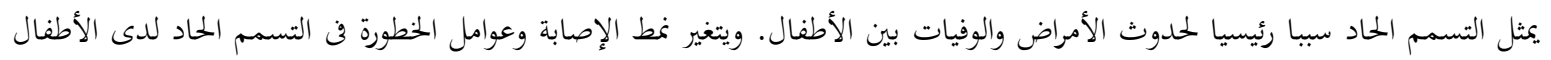

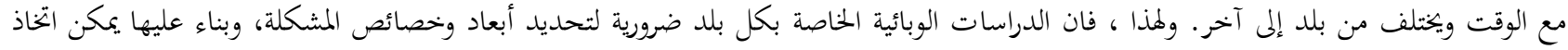
التدابير الوقائية المناسبة.

الهدف من الدراسة: تحدف هذه الدراسة الوبائية الاسترجاعية المى تحديد نمط التسمم الحاد في الأطفال الذين أدخلوا مركز علاج التسمم

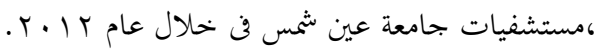

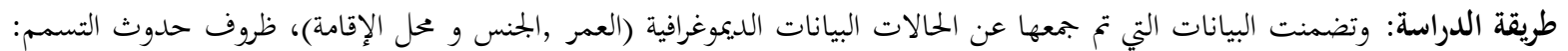

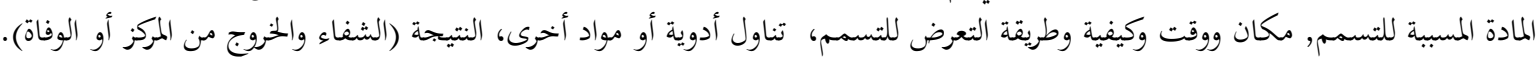

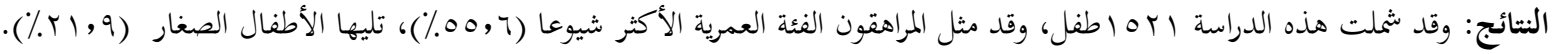

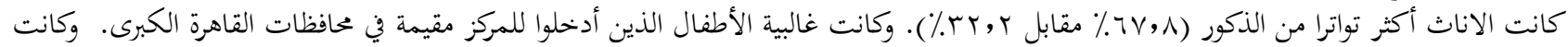

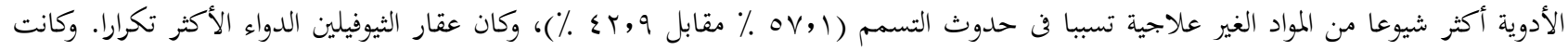

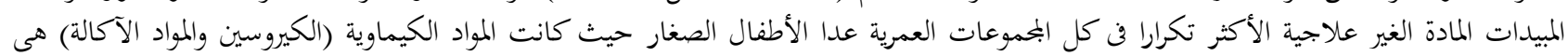

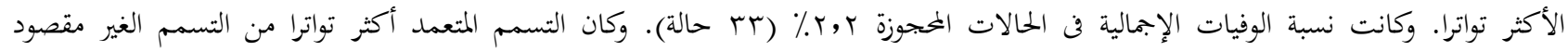

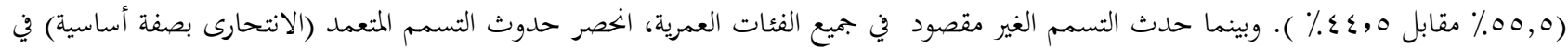

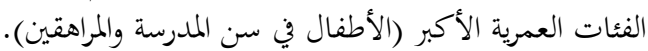

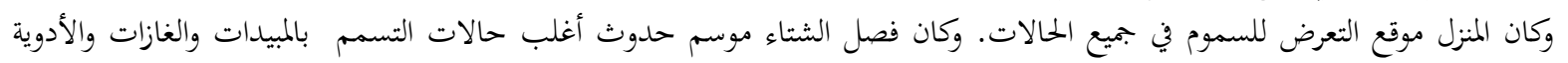

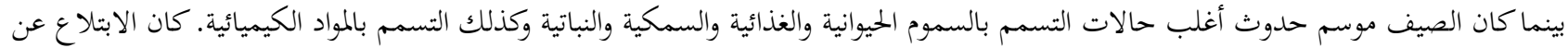

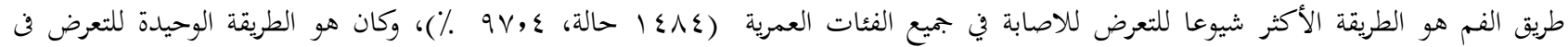

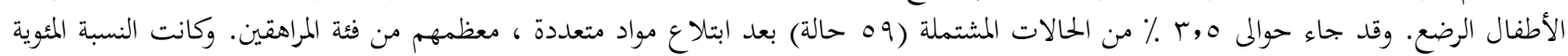

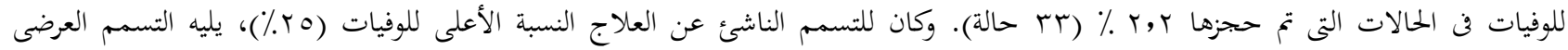

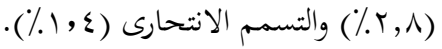

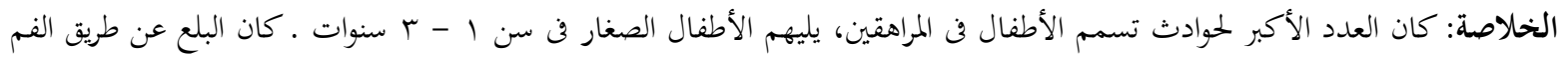

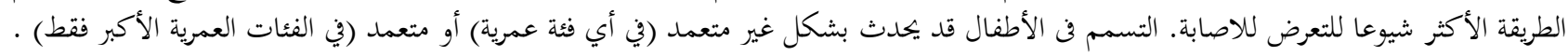

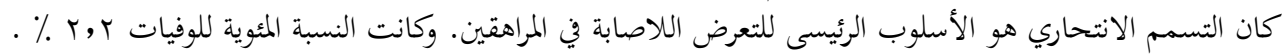

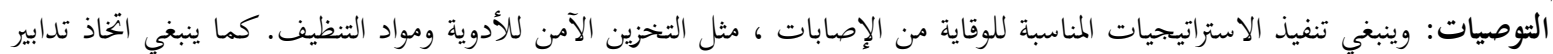
أكثر صرامة على استخدام وتخزين المبيدات. كما ينصح بعمل مزيد من الدراسات على عوامل الخطورة للتسمم المتعمد لدى المراهقين حيث وجد أنه نمط رئيسي للتعرض للتسمم فن هذه 